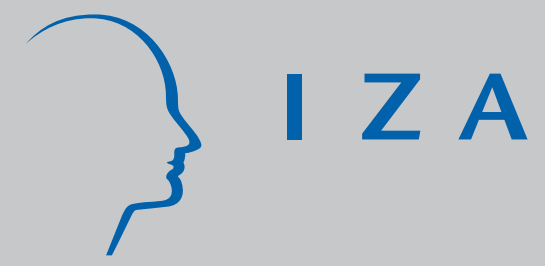

IZA DP No. 8963

Unaccompanied Minors and Separated Refugee Children in Sweden:

An Outlook on Demography, Education and Employment

Aycan Çelikaksoy

Eskil Wadensjö

April 2015

Forschungsinstitut zur Zukunft der Arbeit Institute for the Study of Labor 


\title{
Unaccompanied Minors and Separated Refugee Children in Sweden: An Outlook on Demography, Education and Employment
}

\author{
Aycan Çelikaksoy \\ SOFI and SULCIS, Stockholm University \\ Eskil Wadensjö \\ SOFI and SULCIS, Stockholm University \\ and IZA
}

Discussion Paper No. 8963

April 2015

IZA

P.O. Box 7240

53072 Bonn

Germany

Phone: +49-228-3894-0

Fax: +49-228-3894-180

E-mail: iza@iza.org

Any opinions expressed here are those of the author(s) and not those of IZA. Research published in this series may include views on policy, but the institute itself takes no institutional policy positions. The IZA research network is committed to the IZA Guiding Principles of Research Integrity.

The Institute for the Study of Labor (IZA) in Bonn is a local and virtual international research center and a place of communication between science, politics and business. IZA is an independent nonprofit organization supported by Deutsche Post Foundation. The center is associated with the University of Bonn and offers a stimulating research environment through its international network, workshops and conferences, data service, project support, research visits and doctoral program. IZA engages in (i) original and internationally competitive research in all fields of labor economics, (ii) development of policy concepts, and (iii) dissemination of research results and concepts to the interested public.

IZA Discussion Papers often represent preliminary work and are circulated to encourage discussion. Citation of such a paper should account for its provisional character. A revised version may be available directly from the author. 
IZA Discussion Paper No. 8963

April 2015

\section{ABSTRACT}

\section{Unaccompanied Minors and Separated Refugee Children in Sweden: An Outlook on Demography, Education and Employment ${ }^{*}$}

The number of unaccompanied minors has increased over the past ten years in Sweden, the European country that receives the most children from this group. Some of them emigrate after a period of time in Sweden, but the vast majority stay. Most of the arriving children are teenage boys who have not yet turned 18. However, the largest increase over the latest years is observed for the younger age groups. Furthermore, gender composition is also age dependent, where it is quite balanced for the younger age groups unlike the oldest age group. In the years following their arrival, most of them are enrolled in schools. When it comes to those aged 20 or over, the proportion undergoing education is higher among women but a higher proportion of men are employed. The group that neither works nor studies is much larger among women than among men.

JEL Classification: J13, J15

Keywords: unaccompanied minors, refugee children, migration, education

Corresponding author:

Eskil Wadensjö

Swedish Institute for Social Research

University of Stockholm

SE-106 91 Stockholm

Sweden

E-mail: Eskil.Wadensjo@sofi.su.se

\footnotetext{
* We would like to thank Alireza Behtoui, Berit Berg, and Christer Gerdes for their comments on a previous version, as well as for comments at two conferences: NMRC in Copenhagen on 13 August 2014 and IMISCOE in Madrid on 27 August 2014.
} 


\title{
Unaccompanied Minors and Separated Refugee Children in Sweden: An Outlook on Demography, Education and Employment
}

\author{
Aycan Çelikaksoy and Eskil Wadensjö
}

This report is written as a part of the project "Unaccompanied Minors and Separated Refugee Children in Sweden” which is funded by the European Refugee Fund. This report provides a general background to the development and demographic makeup of the migration of unaccompanied minors to Sweden, as well as looking at their educational and employment characteristics.

Children under 18 years of age who are outside their country of origin and separated from both parents and their legal/customary caregiver are defined as unaccompanied minors/separated children. In Sweden, unaccompanied minors arrive predominantly as asylum seekers instead of through other channels. This fact, combined with high quality data facilities provide a unique opportunity to collect data on a wide range of issues for the whole population of this group as well as following them through time. This project constructs a data set through different registers of Statistics Sweden, The Migration Board as well as the National Board of Health and Welfare including a wide range of longitudinal information on the whole population of unaccompanied minors such as demographic characteristics, living conditions, education, labour market characteristics, family connections, asylum application procedures as well as health.

For the current study only a part of the data set is utilized. The whole population of unaccompanied minors who are registered ${ }^{1}$ in Sweden during the period of 2003 to 2012 are analysed. In addition to the demographic makeup of this type of migration flow we also look at how they have fared since they arrived in Sweden, received residence permits, and were entered into the population registers. ${ }^{2}$

All studies within this project are based on anonymised data covering the entire period of our study. ${ }^{3}$ However, we also use other sources, such as reports and statistics from various

\footnotetext{
${ }^{1}$ We would like to emphasise that our study focuses on those who have been entered into the Swedish population register, and that the "year of arrival” in our data is the year when the unaccompanied minors were registered in Sweden for the first time.

${ }^{2}$ The Swedish Migration Board's website contains information about how many unaccompanied minors seek asylum each year, and how many of them are permitted to stay.

3 There are studies of unaccompanied minors in Norway that are based on register data. See Aalandslid and Walstad Enes (2012) and Stabell Wiggen (2014).
} 
authorities and international organisations, as well as research on unaccompanied minors in Sweden and other countries. Register data can provide very interesting information, but it does not provide information about, for example, the unaccompanied minors' living conditions in their home country or on their way to Sweden ${ }^{4}$ or how they assess their own situation in the country they have fled to. ${ }^{5}$

In future reports, we will study various issues concerning unaccompanied minors more closely, such as their health situation and their work and education in Sweden. ${ }^{6}$

\section{An increasing number of unaccompanied minors}

The conditions for unaccompanied asylum-seeking minors have become one of the key issues in the debate and research on the asylum process, refugee immigration, and integration. An unaccompanied minor is a child under the age of 18 who comes to Sweden unaccompanied by a parent or other legal guardian. Children arriving alone without their parents are in a very vulnerable situation, and thus it is especially important to see what happens to children who are part of this group and follow these children through their youth and adulthood with regard to a wide range of outcomes. Such a study may provide a basis for various measures to improve the conditions for this group.

According to the latest yearly report of the United Nations High Commissioner for Refugees, 51.2 million individuals were forcibly displaced by the end of 2013, where 86 percent of this population is hosted by developing countries and children below 18 years constituted 50 percent of the displaced populations (UNHCR, 2014). Children are a very important part of the displaced populations and the numbers of unaccompanied minors have been growing. However, we do not know what proportion of the total number of children are unaccompanied minors at majority of the borders.

\footnotetext{
${ }^{4}$ Since this is a register study based on Swedish registers, we have only very limited information about the unaccompanied minors' time in their home country. When it comes to such information, interview studies can provide much more knowledge. See, for example, Backlund et al. (2012), Stretmo and Melander (2013), and Bunar (2012).

${ }^{5}$ See e.g. Ní Raghallaigh (2013), a study of the extent to which unaccompanied minors in Ireland feel trust in various respects. Such information cannot be obtained from register data. A study based on both register data and interviews is Eide (2000), which deals with unaccompanied minors in Norway.

${ }^{6}$ For an overview of literature on the health situation of unaccompanied minors, see Eide and Hjern (2013). Vervliet et al. (2014) presents a study of mental health among unaccompanied minors in Belgium and Norway, Nielsen et al. (2008) presents a study relating to Denmark, and Aronsson et al. (2009) presents a study relating to Sweden.
} 
According to the same report 25,300 asylum applications were lodged in 77 countries in 2013 by unaccompanied and separated children (UASC) (UNHCR, 2014). However, this figure shows the asylum applications lodged and is far from the real numbers of unaccompanied minors on the move. During the same year one single border patrol (South Texas) reported 38,833 UASC and they expected this number to double within the next year. Thus, we are far from having the real numbers of unaccompanied minors.

Sweden has been the third country regarding the number of asylum claims within the EU for the last two years and Sweden registered the greatest number of asylum claims by UASC in 2013 and $2014^{7}$. In Sweden unaccompanied minors arrive predominantly as asylum seekers instead of through other channels and around 82 percent each year are granted a permanent residence permit. Thus, we have a unique opportunity to follow the whole population of unaccompanied minors who are registered in Sweden.

The responsibilities for unaccompanied minors in Sweden have been shifted since $1^{\text {st }}$ of July 2006 from the Migration Board to the local governments. The Migration Board is responsible for the asylum investigation and to subsidize local governments for their responsibilities. In addition, the National Board of Health and Welfare is responsible for supervising the municipalities and developing guidance, recommendations and supervision for the care. When a child enters Sweden he or she spends some time in an arrival centre after which a municipality if found to cover reception. During the asylum seeking process all unaccompanied minors get a temporary guardian. The child gets a permanent guardian if a permanent stay is granted. In municipalities the social services take care of the living situation and the daily care. All children have the right to start school immediately after arrival regardless of the stage of their asylum claims.

At the Migration Board, there is different information about the number of unaccompanied minors who arrived in a specific year. This is because the information refers to children at different stages of the asylum process. Not all those seeking asylum will be granted a residence permit, and those seeking asylum may have their applications granted the year after they arrive in Sweden. It takes time for the Migration Board to process an application, and those who are rejected can appeal the Migration Board's decision. Cases involving unaccompanied minors are given priority, and the Migration Board's aim is for a decision to be made within three months; however, on average it takes a little longer. How long it takes

\footnotetext{
${ }^{7}$ Although more UASC crossed the Italian border, they do not appear in these figures since they were in the form of irregular or undocumented flows rather than asylum claims.
} 
may vary depending on how complicated the case is. The data used for the current paper includes those who have been entered into the population register, but we will present the number of asylum seekers from other sources. If there are many asylum seekers in a particular year, the number of people granted permission to stay will increase both that and the following year.

The number and situation of unaccompanied minors are of particular interest from a Swedish perspective, as this type of immigration to Sweden is extensive compared to other European countries, both in relation to population size and in absolute terms. In 2013, the total number of unaccompanied minors seeking asylum in the EU28 countries was 12,730, according to Eurostat. Sweden received the largest group: 3,852 children. Germany $(2,485)$, the United Kingdom (1,265), and Austria (935) came next. Looking at the development between 2008 and 2013, the total number of unaccompanied minors seeking asylum in EU countries is about the same from year to year, but the distribution between destination countries has changed during this period. The number of asylum claims by unaccompanied minors in Sweden and Germany has increased significantly, while the number of claims in the United Kingdom and the Netherlands has decreased.

The unaccompanied minors arriving in Sweden are generally refugees or in need of protection. Most of those who apply for a residence permit have their applications granted. Out of the 1,955 unaccompanied minors who were granted residence permits by the Swedish Migration Board (which is the first instance) in 2013, ${ }^{8} 384$ were granted residence permits as Convention refugees, 1,093 as persons in need of protection, 465 due to particularly distressing circumstances, and 13 for other reasons. In the same year, 435 applications were rejected, an additional 166 were rejected with reference to the Dublin Regulation, ${ }^{9}$ and 386 people withdrew their application or left the country without formally withdrawing their application.

Internationally, there is a widespread discussion about unaccompanied minors who arrive for various reasons. In countries such as Italy and the United States, many children come as "undocumented" migrant workers. ${ }^{10}$ In addition, there is extensive migration in the form of

\footnotetext{
${ }^{8}$ More children may have been granted permits by a migration court or the Migration Court of Appeals after appealing the Migration Board's decision.

${ }^{9}$ The Dublin Regulation stipulates that an asylum application should be processed in the EU country to which a refugee first arrived.

${ }^{10}$ For an overview of the research on unaccompanied minors coming to work, see Edmonds and Shrestha (2013).
} 
trafficking to and from countries on different continents. ${ }^{11}$ The majority of the unaccompanied minors who come to the United States are boys (between 60 and 75 per cent, according to different estimates). Three quarters come from the northern part of Central America called the "Northern Triangle” (Honduras, El Salvador, and Guatemala). There has been a dramatic increase in the number of unaccompanied minors from these countries to the United States in recent years. See Renwick (2014) and Stinchcomb and Hershberg (2014).

There may be several different explanations for a child arriving without an accompanying parent or other legal guardian. The child might be the first to make it to Sweden, while other family members are still trying to come here. Thus, in some cases, the child might be the first step of a family migration, and the parents will come to Sweden later. In other cases, one or both parents have arrived before the child. Children or parents not arriving at the same time may be due to a lack of opportunities - financial or otherwise - to escape together. Another possibility is that the child is orphaned and has no other legal guardian.

In some cases, the child may arrive unaccompanied by an adult, but in other cases, they arrive together with other adult asylum seekers, such as older siblings or other adult relatives who are not their legal guardians. In some cases, the child already has relatives in Sweden, while in other cases, the child does not have any relatives living here. This suggests that the situation upon arrival can be very different for different children. Here we would like to emphasise that more children arrive with their parents or another legal guardian than those who arrive as unaccompanied minors, even from the countries from which many unaccompanied minors come. ${ }^{12}$ In Sweden, 23 percent of all children arriving through the asylum channel were unaccompanied minors in 2013, where this figure was 31 percent in 2014.

Out of the 9,975 unaccompanied minors included in our study, 2,037 have also had their mother in Sweden. ${ }^{13} 637$ of the mothers were registered after the child, 917 before the child, and 481 at the same time ${ }^{14}$ as the child. 1,086 of the unaccompanied minors have had their father in Sweden. ${ }^{15}$ In 342 cases, the father was registered after the child, 641 were registered

\footnotetext{
${ }^{11}$ See ILO (2009) which, referring to a previous ILO study, estimated the number of children in a trafficking situation to 1.2 million in 2000.

${ }^{12}$ In the next report, we will compare what happens to unaccompanied minors compared to what happens to other children from the same country who arrive together with a parent or other legal guardian.

${ }^{13}$ For an additional 295 mothers, there are ID numbers that can be matched to an individual, but we do not have any further information.

${ }^{14}$ That is, they were registered at the same time, but arrived at different times; otherwise, the child would not have been classified as an unaccompanied minor.

${ }^{15}$ For an additional 144 fathers, there are ID numbers that can be matched to an individual, but we do not have any further information.
} 
before the child, and 103 at the same time ${ }^{16}$ as the child. These numbers show that more than a few unaccompanied minors have parents who have also come to Sweden, but that most of them do not.

\section{Extent and demographic makeup}

The number of unaccompanied minors has increased significantly since 2003 (the first year for which we have statistical data in our material). In Table 1, we specify how many were entered into the population register each year, i.e. not the number of asylum seekers.

Table 1. Number of unaccompanied asylum-seeking minors registered between 2003 and 2012, divided by gender

\begin{tabular}{|l|l|l|l|l|}
\hline Year of arrival & Girls & $\begin{array}{l}\text { Proportion of girls } \\
(\%)\end{array}$ & Boys & Total \\
\hline 2003 & 127 & 34 & 242 & 369 \\
\hline 2004 & 51 & 46 & 60 & 111 \\
\hline 2005 & 30 & 45 & 37 & 67 \\
\hline 2006 & 68 & 38 & 111 & 179 \\
\hline 2007 & 150 & 18 & 673 & 823 \\
\hline 2008 & 164 & 22 & 583 & 747 \\
\hline 2009 & 221 & 24 & 688 & 909 \\
\hline 2010 & 294 & 23 & 1012 & 1306 \\
\hline 2011 & 261 & 14 & 1670 & 1931 \\
\hline 2012 & 1092 & 31 & 2441 & 3533 \\
\hline
\end{tabular}

Note: Some of those in the 2003 group were registered prior to that year.

We can see that the proportion of girls decreased, with some deviation, until 2011, and then increased significantly in 2012. The total proportion of girls during the studied time period is only a quarter of the total number of unaccompanied minors (see Table 2). It is important to try to explain this pattern, as well as the differences between boys and girls when it comes to age and country of birth. A possible explanation is differences in gender roles between

\footnotetext{
${ }^{16}$ That is, they were registered at the same time, but arrived at different times; otherwise, the child would not have been classified as an unaccompanied minor.
} 
different countries. Here we have to rely on existing qualitative studies and will return to this issue in future reports.

The number of unaccompanied minors continues to increase. ${ }^{17}$ In 2013, 3,852 unaccompanied minors sought asylum in Sweden. Out of the 2,942 cases that were decided that year, 66 per cent were granted asylum. Please note that the number of cases resolved during the year is much lower than the number of asylum seekers the same year. The average processing time was 120 days in 2013 and 143 days in 2014. In 2014, 7,049 unaccompanied minors sought asylum. Not everyone will have their application granted, but if the proportion is about the same as before, it will be a clear increase compared to 2013.

The total number of unaccompanied minors increases each year during the time period covered by our study (the values for each year are combined in order to see the total number of unaccompanied minors who have arrived and are still registered here). In Table 2, we show the change in the total number of unaccompanied minors who have arrived and remain in Sweden each year.

Table 2. Number of unaccompanied asylum-seeking minors entered into the Swedish population register between 2003 and 2012, divided by gender - cumulative numbers

\begin{tabular}{|l|l|l|l|l|}
\hline $\begin{array}{l}\text { Year of first } \\
\text { registration }\end{array}$ & Girls & $\begin{array}{l}\text { Proportion of } \\
\text { girls (\%) }\end{array}$ & Boys & Total \\
\hline 2003 & 127 & 34 & 242 & 369 \\
\hline 2004 & 178 & 37 & 302 & 480 \\
\hline 2005 & 207 & 38 & 339 & 546 \\
\hline 2006 & 272 & 38 & 446 & 718 \\
\hline 2007 & 420 & 27 & 1116 & 1536 \\
\hline 2008 & 582 & 26 & 1697 & 2279 \\
\hline 2009 & 799 & 25 & 2378 & 3177 \\
\hline 2010 & 1091 & 24 & 3384 & 4475 \\
\hline 2011 & 1349 & 21 & 5043 & 6392 \\
\hline 2012 & 2431 & 25 & 7466 & 9897 \\
\hline
\end{tabular}

Note: These are cumulative numbers, which means that the data for 2012 include all those registered before or during 2012 (the population of the study). This means that 9,897, which is the number for 2012, is the total sum of those who arrived between 2003 (or, in some cases, even earlier) and 2012 (minus those who have emigrated or died).

\footnotetext{
${ }^{17}$ The numbers in this section are based on information from the Swedish Migration Board.
} 
The 9,897 unaccompanied minors who were registered by 2012 and remained in the country do not include everyone who came to Sweden as an unaccompanied minor during the same time period. Some have died, while others have left the country, either by moving back or moving on to another country.

80 of the unaccompanied minors who were registered between 2003 and 2012 have emigrated: 53 boys and 27 girls. ${ }^{18}$ This means that the proportion of girls who have emigrated is slightly higher than the corresponding proportion of boys. Most of those who have left Sweden did so in the year they turned 18 or later; this group includes 42 boys and 20 girls. The average age at the time of emigration for both boys and girls is 19. Furthermore, 38 of those registered between 2003 and 2012 left the country in 2013. The proportion that emigrated is higher among those who arrived in the first few years than among those who arrived later, for obvious reasons: those who came early have had more time to emigrate. The largest group moved to countries that are part of the EEA, i.e. within Europe; the second largest group moved to an unspecified country. In addition, many of them moved to Iraq, which might be a case of return migration to the northern Kurdish part of Iraq that has had a relatively strong economic development.

Ten of the unaccompanied minors died between 2003 and 2012, and five died in $2013-13$ boys and two girls. Ten of them were aged 18 or over the year they died, and five were younger than 18. Some of those who died had been in Sweden for only a few years, while others had been here for many years. Seven of the ten deaths occurred within three years of being entered into the population register.

Those who apply to stay as unaccompanied minors come from many different countries, although most of them come from a few select countries. In 2013, most of them came from Afghanistan (1,247), Somalia (576), Syria (364), and Eritrea (345). The proportion of minors from these countries whose applications are granted is also high. In 2014, most unaccompanied minors who sought asylum came from the same few countries, i.e. Afghanistan (1,547), Eritrea (1,456), Syria (1,233), and Somalia $(1,118)$, although the distribution between the countries is slightly different.

\footnotetext{
${ }^{18}$ There may be unregistered emigration. Not everyone who moves out of Sweden reports this to the Swedish Tax Agency, which is the authority responsible for the population register. See Wadensjö (2013).
} 
Table 3 shows that, with a few exceptions, most of those who were registered between 2003 and 2012 came from Iraq, Somalia, Afghanistan, and Eritrea.

In the table, we have listed the proportion of girls in parentheses. We should note that the number of registered unaccompanied minors was low until 2005, and, consequently, that the percentages for these years are based on a low number of observations. If we compare the proportion of girls from different countries for the years 2006-2012, we find that it is very low among those born in Afghanistan and Iraq, while it is much higher among those born in Eritrea and Somalia (as well as the rest of Africa and the rest of Asia).

Table 3. The four countries from which the largest number of unaccompanied minors was registered each year (by country of birth); the proportion of girls is listed in parentheses

\begin{tabular}{|l|l|l|l|l|}
\hline Year & $\begin{array}{l}\text { Largest } \\
\text { number }\end{array}$ & $\begin{array}{l}\text { Second largest } \\
\text { number }\end{array}$ & $\begin{array}{l}\text { Third } \\
\text { number }\end{array}$ & Fourth largest number \\
\hline 2003 & Iraq (14) & Somalia (58) & Afghanistan (11) & Rest of Africa (56) \\
\hline 2004 & Somalia (53) & $\begin{array}{l}\text { Rest of Africa } \\
(67)\end{array}$ & Afghanistan (0) & Rest of Europe (57) \\
\hline 2005 & $\begin{array}{l}\text { Somalia/ Rest } \\
\text { of Africa } \\
(56) /(39)\end{array}$ & Iraq (43) & Afghanistan (33) & $\begin{array}{l}\text { Eritrea/Rest of Europe } \\
\text { (0)/(50) }\end{array}$ \\
\hline 2006 & Iraq (25) & Somalia (61) & Afghanistan (5) & Eritrea (54) \\
\hline 2007 & Iraq (11) & Afghanistan (2) & Somalia (41) & Rest of Africa (28) \\
\hline 2008 & Iraq (11) & Somalia (44) & Afghanistan (3) & Rest of Africa (50) \\
\hline 2009 & Somalia (42) & Afghanistan (2) & Iraq (15) & Eritrea (58) \\
\hline 2010 & $\begin{array}{l}\text { Afghanistan } \\
(1)\end{array}$ & Somalia (44) & Iraq (29) & Eritrea (43) \\
\hline 2011 & $\begin{array}{l}\text { Afghanistan } \\
(5)\end{array}$ & Somalia (35) & Iran (17) & Eritrea (53) \\
\hline 2012 & $\begin{array}{l}\text { Afghanistan } \\
(11)\end{array}$ & Somalia (44) & Rest of Asia (46) & Eritrea (56) \\
\hline
\end{tabular}

Note: We do not have separate data from all countries; some countries are grouped together. This explains the existence of the Rest of Europe, Rest of Africa, and Rest of Asia categories in this table. When it comes to European countries, we have separate data for the Soviet Union, Yugoslavia, and Albania. Other European countries are included in the Rest of Europe category. When it comes to Africa, we have separate data for Algeria, Eritrea, Ethiopia, Gambia, Morocco, Somalia, and Uganda; for Asia, we have separate data for Afghanistan, Iraq, Iran, Syria, and Turkey. Others born in Africa or Asia are included in the Rest of North Africa, Rest of Africa, Rest of the Middle East, and Rest of Asia categories. 


\section{To which parts of Sweden do the unaccompanied minors arrive?}

In which parts of Sweden do the unaccompanied minors live once they have been granted a residence permit and entered into the population register? Here we will present where they lived during their first year as residents in Sweden; in a future report, we will study their mobility during their stay here. It turns out that they are spread out across all counties in Sweden, albeit with slightly greater numbers in the major cities; see Table 4. However, if we look at the size of the population in the various counties, the major cities are not heavily overrepresented.

Table 4. The four counties where the most unaccompanied minors lived the first year after being registered in Sweden; the percentage of all unaccompanied minors registered the same year is listed in parentheses.

\begin{tabular}{|c|c|c|c|c|}
\hline Year & Largest number & $\begin{array}{ll}\begin{array}{l}\text { Second } \\
\text { number }\end{array} & \text { largest } \\
\end{array}$ & $\begin{array}{ll}\begin{array}{l}\text { Third } \\
\text { number }\end{array} & \text { largest } \\
\end{array}$ & $\begin{array}{l}\text { Fourth } \\
\text { number }\end{array}$ \\
\hline 2003 & $\begin{array}{l}\text { Stockholm } \\
\text { County (27) }\end{array}$ & $\begin{array}{l}\text { Västra Götaland } \\
\text { County (18) }\end{array}$ & Skåne County (9) & $\begin{array}{l}\text { Västernorrland } \\
\text { County/Örebro } \\
\text { County (7) }\end{array}$ \\
\hline 2004 & $\begin{array}{l}\operatorname{lm} \\
(23)\end{array}$ & $\begin{array}{l}\text { Västerbotten } \\
\text { County (13) }\end{array}$ & $\begin{array}{l}\text { Västra Götaland } \\
\text { County/Uppsala } \\
\text { County (11) }\end{array}$ & Örebro County (10) \\
\hline 2005 & $\begin{array}{l}\text { berg } \\
(16)\end{array}$ & $\begin{array}{l}\text { Stockholm County } \\
\text { (13) }\end{array}$ & $\begin{array}{l}\text { Östergötland } \\
\text { County (11) }\end{array}$ & $\begin{array}{lr}\text { Skåne } & \text { County/ } \\
\text { Västra } & \text { Götaland } \\
\text { County/ } & \text { Örebro } \\
\text { County (8) } & \end{array}$ \\
\hline 2006 & m & $\begin{array}{l}\text { Västerbotten } \\
\text { County (16) }\end{array}$ & Skåne County (13) & $\begin{array}{l}\text { Västra Götaland } \\
\text { County (11) }\end{array}$ \\
\hline 2007 & $\begin{array}{l}\text { Stockholm } \\
\text { County (30) }\end{array}$ & $\begin{array}{l}\text { Västra Götaland } \\
\text { County (15) }\end{array}$ & $\begin{array}{l}\text { Västerbotten } \\
\text { County (12) }\end{array}$ & Skåne County (11) \\
\hline 2008 & $\begin{array}{l}\text { Stockholm } \\
\text { County (22) }\end{array}$ & Skåne County (9) & $\begin{array}{l}\text { Västra Götaland } \\
\text { County (8) }\end{array}$ & $\begin{array}{l}\text { Västerbotten County } \\
\text { (6) }\end{array}$ \\
\hline 2009 & $\begin{array}{l}\text { Stockholm } \\
\text { County (16) }\end{array}$ & $\begin{array}{l}\text { Västerbotten } \\
\text { County (9) }\end{array}$ & $\begin{array}{l}\text { Norrbotten County } \\
\text { (8) }\end{array}$ & $\begin{array}{l}\text { Västra Götaland } \\
\text { County (7) }\end{array}$ \\
\hline 2010 & $\begin{array}{l}\text { Stockholm } \\
\text { County (19) }\end{array}$ & Skåne County (12) & $\begin{array}{l}\text { Västra Götaland } \\
\text { County (11) }\end{array}$ & $\begin{array}{l}\text { Västerbotten County } \\
\text { (7) }\end{array}$ \\
\hline 2011 & $\begin{array}{l}\text { Stockholm } \\
\text { County (14) }\end{array}$ & Skåne County (13) & $\begin{array}{l}\text { Västra Götaland } \\
\text { County (12) }\end{array}$ & $\begin{array}{l}\text { Västerbotten County } \\
\text { (7) }\end{array}$ \\
\hline 2012 & $\begin{array}{l}\text { Stockholm } \\
\text { County (20) }\end{array}$ & $\begin{array}{l}\text { Västra Götaland } \\
\text { County (18) }\end{array}$ & Skåne County (6) & $\begin{array}{l}\text { Västerbotten County } \\
\text { (5) }\end{array}$ \\
\hline
\end{tabular}

Table 5 lists the top four municipalities each year where the most unaccompanied minors lived the first year after being registered in Sweden. Stockholm, Gothenburg, and Malmö are represented most years, while it varies which other municipalities are represented. Many of 
those registered during certain years reside in municipalities with relatively few inhabitants, such as Alvesta and Härnösand.

There is an ongoing discussion about which factors affect the geographical placement; for example, what importance the presence of relatives already residing in the country has. We will return to this issue in a future report.

Table 5. The four municipalities where the most unaccompanied minors lived the first year after being registered in Sweden; the percentage of all unaccompanied minors registered the same year is listed in parentheses.

\begin{tabular}{|l|l|l|l|l|}
\hline Year & Largest number & $\begin{array}{l}\text { Second largest } \\
\text { number }\end{array}$ & Third largest number & $\begin{array}{l}\text { Fourth largest } \\
\text { number }\end{array}$ \\
\hline 2003 & Stockholm (14) & Gothenburg (8) & Härnösand (7) & Malmö (6) \\
\hline 2004 & Stockholm (17) & Skellefteå (12) & Härnösand (9) & Uppsala (5) \\
\hline 2005 & Alvesta (12) & Stockholm (9) & $\begin{array}{l}\text { Härnösand/ } \\
\text { Skellefteå/Karlskrona (6) }\end{array}$ & Mjölby/Hjo (5) \\
\hline 2006 & Skellefteå (14) & Stockholm (12) & Gothenburg (6) & Malmö (6) \\
\hline 2007 & Stockholm (17) & Malmö (6) & Gothenburg (6) & Skellefteå (5) \\
\hline 2008 & Stockholm (11) & Gothenburg (4) & Eskilstuna (3) & Malmö (3) \\
\hline 2009 & Stockholm (10) & Gothenburg (3) & Uppsala (3) & Skellefteå (2) \\
\hline 2010 & Stockholm (9) & Gothenburg (4) & Uppsala (2) & Växjö (2) \\
\hline 2011 & Stockholm (5) & Malmö (3) & Uppsala (3) & Gothenburg (2) \\
\hline 2012 & Stockholm (9) & Gothenburg (6) & Malmö (3) & Örebro (2) \\
\hline
\end{tabular}

\section{At what age do the unaccompanied minors arrive?}

Those who are granted asylum as unaccompanied minors must be below 18 years of age at the time of application. In order to show how old the unaccompanied minors are when they are registered in Sweden, we provide a detailed breakdown of the age distribution among those who were entered into the population register for the first time in 2011 or 2012.

As we can see in Table 6, most are between 15 and 17 years old. At that age, opportunities to travel on their own are much greater than for those who are younger. In addition, we can see that more than a few are 18 years old. This does not mean that they were 18 years old when they were registered, but that they turned 18 the year that they were registered (for example, they may have been 17 and a few months when they arrived, either 17 or 18 when they 
received a residence permit a few months later, and 18 the year that they were entered into the population register).

In cases where the asylum seekers do not have any documents that clearly show their age, there may be some uncertainty about how old they are. Various more or less reliable methods are used to determine the age of these asylum seekers; see e.g. Schmeling et al. (2006) and Olze et al. (2006). The uncertainty about age has been used by some critics of this type of immigration as an argument against granting residence permits to unaccompanied minors. See Hirvonen (2013) for a discussion on this topic.

Some of those who come to Sweden are very young. Some of them are children of other unaccompanied minors (a young mother or father may arrive with a child, in which case both are classified as unaccompanied minors), but more of them are at an age where it is not possible for them to arrive with parents under the age of 18 , nor is it likely that they were able to come here on their own. Most likely, they arrived together with older unaccompanied siblings or adult relatives who were not their parents or guardians. Out of the children who were five years old or younger when they were registered, twelve arrived with a mother who was also an unaccompanied minor, and two arrived with a father who was an unaccompanied minor. The largest increase in the number of unaccompanied minors have not been observed for the most common group, which is males who are 16 years of age and older. The largest increases in numbers have been observed for younger age groups. The large increases in the younger age groups are especially concerning. Furthermore, we can see that the gender composition is quite different across the different age groups, while 50 percent of those who are 11 years old or younger are females, only 25 percent of the older age group are females. 
Table 6. Age distribution among unaccompanied minors who were registered in 2011 and 2012 - number of children.

\begin{tabular}{|l|l|l|l|l|}
\hline \multirow{2}{*}{ Age } & Girls & \multicolumn{2}{l|}{ Boys } \\
\cline { 2 - 5 } & 2011 & 2012 & 2011 & 2012 \\
\hline 0 & 0 & 9 & 0 & 19 \\
\hline 1 & 0 & 11 & 0 & 11 \\
\hline 2 & 0 & 15 & 0 & 11 \\
\hline 3 & 1 & 21 & 0 & 14 \\
\hline 4 & 1 & 21 & 1 & 28 \\
\hline 5 & 2 & 27 & 3 & 29 \\
\hline 6 & 4 & 40 & 1 & 28 \\
\hline 7 & 6 & 48 & 6 & 40 \\
\hline 8 & 0 & 48 & 7 & 43 \\
\hline 9 & 5 & 46 & 7 & 64 \\
\hline 10 & 2 & 67 & 7 & 70 \\
\hline 11 & 8 & 62 & 9 & 60 \\
\hline 12 & 6 & 64 & 15 & 77 \\
\hline 13 & 11 & 77 & 37 & 108 \\
\hline 14 & 12 & 68 & 93 & 177 \\
\hline 15 & 32 & 91 & 233 & 305 \\
\hline 16 & 53 & 142 & 513 & 588 \\
\hline 17 & 80 & 148 & 572 & 558 \\
\hline 18 & 36 & 86 & 165 & 210 \\
\hline 19 & 2 & 1 & 1 & 1 \\
\hline
\end{tabular}

As stated above, the age distribution among boys and girls registered in 2011 and 2012, Table 6 shows that it is mainly in the group of older children that there are more boys than girls. This is also the case for those who were registered for the first time in years other than 2011 and 2012.

\section{Education in Sweden ${ }^{19}$}

All those who come to Sweden under the age of 16 are entered into the school system. Many of the older ones are also entered into the school system, and many of them continue to study as young adults. In Table 7, we show the proportion of those who are undergoing education,

\footnotetext{
${ }^{19}$ For an overview of literature on young migrants' education in Sweden, see Tallberg Broman (2014) and Olsson, Lundqvist, and Behtoui (2012). For a study of the situation in Norway, see Thorshaug and Svendsen (2014).
} 
divided by age and gender. Here we have merged those who arrived at different times, so the 20-year-olds may have been registered in Sweden for different periods of time.

Most of those who are 21 years old or younger are undergoing education (measured in the autumn each year). There is a decline in the proportion who are under education after age 21 , especially in the case of males. This might be partly due to the fact that 21 is the highest age at which young people receive support. Young people in education are supported fully until the age of 21. This is the case irrespective of their educational situation and their legal status. For those wishing to continue education after the age of 21, loans can be provided by the state in the same way as for Swedish students. Young people in the asylum procedure can continue their education until a decision is made on their status. We have probably underestimated the proportions, as we lack information about participation in introductory language training. Up until the age of 20, it is more common for men to study than women. Among unaccompanied minors who have turned 21 or older, it is more common for women to study than men. The latter is consistent with the general pattern in Sweden: more women pursue higher education than men.

Table 7. Proportion (\%) of those aged 16-27 undergoing education at different ages.

\begin{tabular}{|l|l|l|}
\hline Age & Women & Men \\
\hline 16 & 68 & 70 \\
\hline 17 & 74 & 82 \\
\hline 18 & 84 & 92 \\
\hline 19 & 77 & 88 \\
\hline 20 & 62 & 67 \\
\hline 21 & 56 & 50 \\
\hline 22 & 43 & 35 \\
\hline 23 & 38 & 29 \\
\hline 24 & 40 & 26 \\
\hline 25 & 36 & 24 \\
\hline 26 & 22 & 26 \\
\hline 27 & 23 & 15 \\
\hline
\end{tabular}

Education may take place at different levels that vary with age, but also depending on what education the unaccompanied minors have when they come to Sweden. See Table 8 for an overview of ongoing education at different ages. 
Table 8. Proportion (\%) of students undergoing different types of education, divided by age.

a) Men

\begin{tabular}{|c|c|c|c|c|c|c|c|c|c|c|c|c|}
\hline \multirow[t]{2}{*}{ Type of education } & \multicolumn{12}{|c|}{ Age } \\
\hline & 16 & 17 & 18 & 19 & 20 & 21 & 22 & 23 & 24 & 25 & 26 & 27 \\
\hline Upper-secondary school & 81 & 97 & 97 & 92 & 46 & 32 & 0 & 0 & 0 & 0 & 0 & 0 \\
\hline Komvux (adult education) & 0 & 1 & 2 & 4 & 39 & 46 & 50 & 49 & 39 & 35 & 27 & 27 \\
\hline $\begin{array}{l}\text { Technical preparatory } \\
\text { year }\end{array}$ & 0 & 0 & 0 & 0 & 0 & 1 & 1 & 0 & 2 & 0 & 0 & 0 \\
\hline Undergraduate education & 0 & 0 & 0 & 0 & 2 & 7 & 13 & 27 & 41 & 42 & 43 & 36 \\
\hline $\begin{array}{l}\text { Post-secondary vocational } \\
\text { training }\end{array}$ & 0 & 0 & 0 & 0 & 0 & 1 & 1 & 2 & 2 & 2 & 0 & 0 \\
\hline Folk high school & 0 & 0 & 1 & 3 & 6 & 9 & 12 & 9 & 9 & 9 & 14 & 0 \\
\hline $\begin{array}{l}\text { Student aid for studies } \\
\text { abroad }\end{array}$ & 0 & 0 & 0 & 0 & 0 & 0 & 0 & 0 & 0 & 2 & 2 & 0 \\
\hline Other studies & 0 & 0 & 0 & 0 & 2 & 1 & 1 & 2 & 3 & 4 & 2 & 0 \\
\hline Labour market training & 0 & 0 & 0 & 0 & 1 & 3 & 7 & 7 & 6 & 7 & 7 & 27 \\
\hline Primary school & 19 & 2 & 0 & 0 & 0 & 0 & 0 & 0 & 0 & 0 & 0 & 0 \\
\hline $\begin{array}{l}\text { SFI (Swedish for } \\
\text { Immigrants) }\end{array}$ & 0 & 0 & 0 & 0 & 3 & 2 & 6 & 4 & 0 & 0 & 5 & 9 \\
\hline
\end{tabular}

b) Women

\begin{tabular}{|c|c|c|c|c|c|c|c|c|c|c|c|c|}
\hline \multirow[t]{2}{*}{ Type of education } & \multicolumn{12}{|c|}{ Age } \\
\hline & 16 & 17 & 18 & 19 & 20 & 21 & 22 & 23 & 24 & 25 & 26 & 27 \\
\hline Upper-secondary school & 78 & 97 & 98 & 91 & 38 & 23 & 6 & 0 & 0 & 0 & 0 & 0 \\
\hline Komvux (adult education) & 0 & 1 & 1 & 4 & 44 & 50 & 57 & 52 & 50 & 58 & 57 & 67 \\
\hline $\begin{array}{l}\text { Technical preparatory } \\
\text { year }\end{array}$ & 0 & 0 & 0 & 0 & 0 & 0 & 1 & 1 & 0 & 0 & 0 & 0 \\
\hline Undergraduate education & 0 & 0 & 0 & 0 & 4 & 10 & 23 & 29 & 36 & 25 & 21 & 0 \\
\hline $\begin{array}{l}\text { Post-secondary vocational } \\
\text { training }\end{array}$ & 0 & 0 & 0 & 0 & 0 & 1 & 1 & 1 & 3 & 6 & 0 & 0 \\
\hline Folk high school & 0 & 0 & 1 & 2 & 7 & 8 & 4 & 5 & 5 & 3 & 14 & 0 \\
\hline $\begin{array}{l}\text { Student aid for studies } \\
\text { abroad }\end{array}$ & 0 & 0 & 0 & 0 & 0 & 0 & 0 & 2 & 2 & 6 & 0 & 0 \\
\hline Other studies & 0 & 0 & 0 & 0 & 1 & 2 & 1 & 2 & 2 & 0 & 0 & 0 \\
\hline Labour market training & 0 & 0 & 0 & 0 & 1 & 1 & 1 & 1 & 0 & 0 & 0 & 0 \\
\hline Primary school & 21 & 2 & 0 & 0 & 0 & 0 & 0 & 0 & 0 & 0 & 0 & 0 \\
\hline $\begin{array}{l}\text { SFI (Swedish for } \\
\text { Immigrants) }\end{array}$ & 0 & 0 & 0 & 1 & 5 & 6 & 8 & 6 & 3 & 3 & 7 & 33 \\
\hline
\end{tabular}

Here we can see that most 16-year-olds undergoing education is in upper-secondary school, while one out of five is in primary school. Among those aged 17-19, the vast majority are in upper-secondary school. Among those aged 20-21, many are still in upper-secondary school, but it is also common to study at Komvux. For those aged 22 and over, Komvux is the most common type of education, but other types of education, such as undergraduate education, folk high school, and labour market training (for men), are also important. It is important to 
remember that few of the unaccompanied minors had turned 27 years old by 2012. The percentages for those aged 27 are thus based on only a few individuals.

It is very interesting to see what level of education the unaccompanied minors have achieved at different ages; see Table 9. We can see that the level of education is unknown for many of the younger children. In some cases, this might be due to a lack of information, but it is more likely to indicate that they do not have a complete education. For those aged 20 and over, the proportion with a high school degree increases with each year of age - it is more common among women than among men. In addition, some of them have completed a tertiary education degree.

Table 9. Age and highest level of completed education (percentage distribution).

a) Men

\begin{tabular}{|c|c|c|c|c|c|c|}
\hline Age & $\begin{array}{l}\text { Compulsory } \\
\text { school, less than } 9 \\
\text { years }\end{array}$ & $\begin{array}{l}\text { Compulsory } \\
\text { school, } 9 \text { years }\end{array}$ & High school & $\begin{array}{l}\text { Short tertiary } \\
\text { education }\end{array}$ & $\begin{array}{l}\text { Long tertiary } \\
\text { education }\end{array}$ & Unknown \\
\hline 16 & 1 & 21 & 0 & 0 & 0 & 79 \\
\hline 17 & 3 & 14 & 0 & 0 & 0 & 83 \\
\hline 18 & 9 & 14 & 1 & 0 & 0 & 76 \\
\hline 19 & 18 & 19 & 4 & 0 & 0 & 60 \\
\hline 20 & 27 & 25 & 12 & 0 & 0 & 36 \\
\hline 21 & 30 & 26 & 26 & 1 & 0 & 17 \\
\hline 22 & 31 & 24 & 36 & 3 & 1 & 5 \\
\hline 23 & 28 & 21 & 39 & 5 & 2 & 5 \\
\hline 24 & 24 & 22 & 40 & 7 & 4 & 2 \\
\hline 25 & 25 & 19 & 41 & 7 & 7 & 2 \\
\hline 26 & 27 & 16 & 40 & 8 & 9 & 0 \\
\hline 27 & 28 & 19 & 39 & 3 & 12 & 0 \\
\hline
\end{tabular}

b) Women

\begin{tabular}{|c|c|c|c|c|c|c|}
\hline Age & $\begin{array}{l}\text { Compulsory } \\
\text { school, less than } 9 \\
\text { years }\end{array}$ & $\begin{array}{l}\text { Compulsory } \\
\text { school, } 9 \text { years }\end{array}$ & High school & $\begin{array}{l}\text { Short tertiary } \\
\text { education }\end{array}$ & $\begin{array}{l}\text { Long tertiary } \\
\text { education }\end{array}$ & Unknown \\
\hline 16 & 29 & 0 & 0 & 0 & 0 & 71 \\
\hline 17 & 2 & 20 & 0 & 0 & 0 & 78 \\
\hline 18 & 6 & 16 & 2 & 0 & 0 & 77 \\
\hline 19 & 11 & 18 & 6 & 0 & 0 & 65 \\
\hline 20 & 17 & 21 & 13 & 1 & 0 & 48 \\
\hline 21 & 20 & 24 & 27 & 3 & 0 & 27 \\
\hline 22 & 19 & 26 & 38 & 4 & 1 & 13 \\
\hline 23 & 16 & 26 & 41 & 6 & 4 & 7 \\
\hline 24 & 14 & 19 & 50 & 5 & 7 & 6 \\
\hline 25 & 13 & 11 & 55 & 4 & 11 & 6 \\
\hline 26 & 14 & 16 & 50 & 3 & 9 & 8 \\
\hline 27 & 12 & 23 & 50 & 0 & 4 & 12 \\
\hline
\end{tabular}




\section{Employment}

Beneficiaries of international protection have the right to access employment immediately under EU asylum law. However, this is not the case, under EU asylum law, for young asylum seekers who are authorized to work no longer than nine months from the date when the asylum claim was lodged if a first instance decision by then has not been taken. Access to employment is critical for young unaccompanied minors turning 21, as they lose all state support at this age. Social workers in after-care facilities try to facilitate access to work through networks, job shadowing or internships (UNHCR, 2014).

An important part of integration is to find a job and be integrated into the Swedish labour market. In Table 10, we show how big a proportion of those aged 16 and over are employed, divided by age. We can see that very few of the teenagers have a job (most of them study). Many more among those aged 21 and over are employed partly due to reasons discussed above. We can see that the proportion increases with age when we compare different age groups with each other. Here it is important to remember that they have been in Sweden for different periods of time and that the observations are taken from different calendar years. We will take this into account in a future report.

We can see that there are major differences between men and women. There is a much higher proportion of employed men than employed women in each age group. This difference is much greater than among people born in Sweden. It is important to examine this pattern more closely. 
Table 10. Proportion (\%) of unaccompanied minors aged 16-27 with employment.

\begin{tabular}{|l|l|l|}
\hline Age & Women & Men \\
\hline 16 & 0 & 0 \\
\hline 17 & 0 & 1 \\
\hline 18 & 2 & 5 \\
\hline 19 & 9 & 12 \\
\hline 20 & 11 & 19 \\
\hline 21 & 22 & 33 \\
\hline 22 & 29 & 45 \\
\hline 23 & 40 & 53 \\
\hline 24 & 46 & 60 \\
\hline 25 & 51 & 62 \\
\hline 26 & 47 & 65 \\
\hline 27 & 42 & 65 \\
\hline
\end{tabular}

Note: Proportion with employment during a reference week in November each year, according to register-based employment statistics from Statistics Sweden.

An important question is what kind of jobs the unaccompanied minors have. Here we will present information about occupations based on a relatively rough division into ten fields of work; see Table 11. 
Table 11. Percentage distribution across different occupations for those aged 18 and over with employment.

a) Men

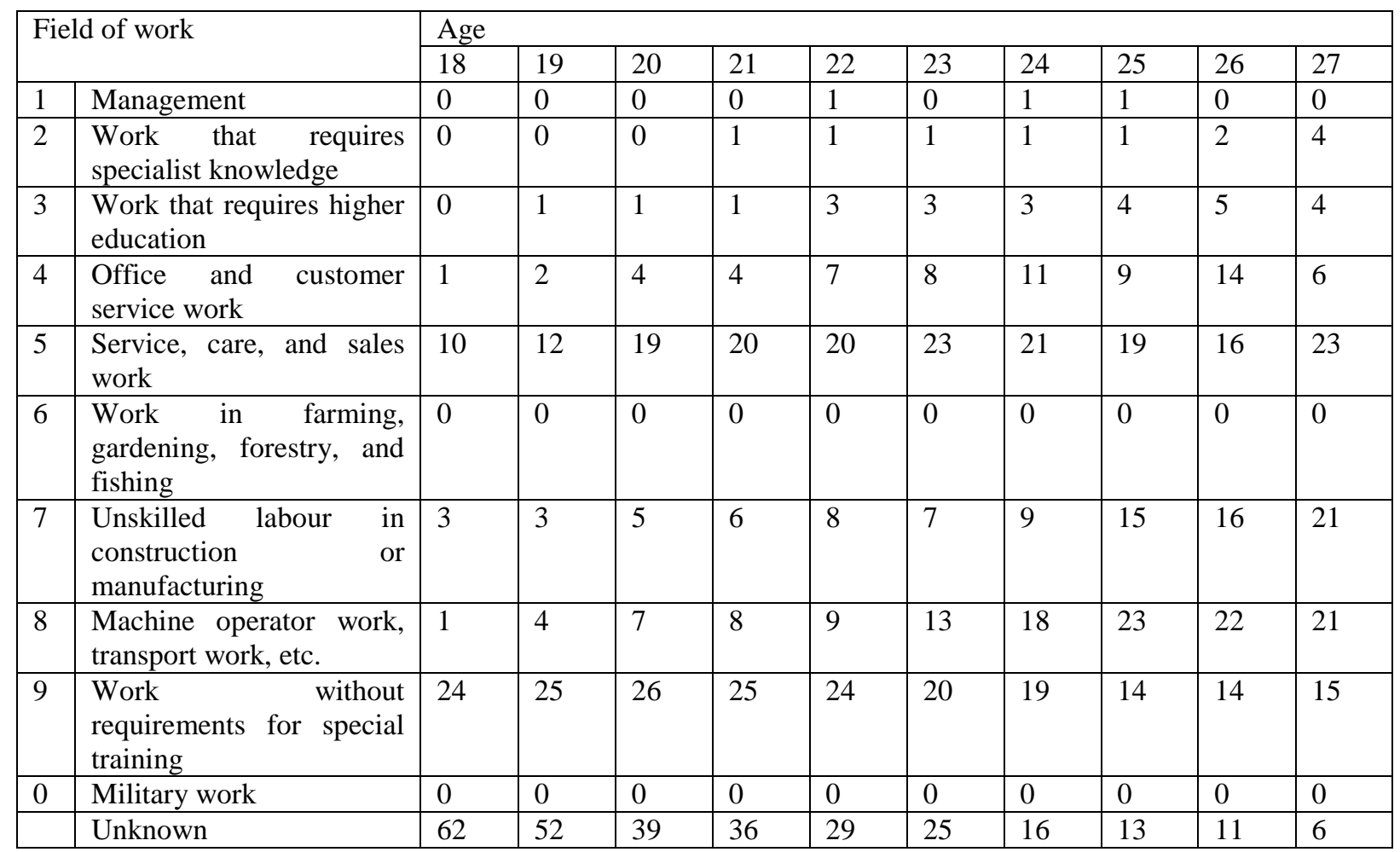

b) Women

\begin{tabular}{|c|c|c|c|c|c|c|c|c|c|c|c|}
\hline \multirow{2}{*}{\multicolumn{2}{|c|}{ Field of work }} & \multicolumn{10}{|c|}{ Age } \\
\hline & & \multirow{2}{*}{$\begin{array}{l}18 \\
0 \\
\end{array}$} & \multirow{2}{*}{$\begin{array}{ll}19 \\
0 \\
\end{array}$} & \multirow{2}{*}{$\begin{array}{l}20 \\
0 \\
\end{array}$} & \multirow{2}{*}{$\begin{array}{l}21 \\
0 \\
\end{array}$} & \multirow{2}{*}{\begin{tabular}{|l|}
22 \\
0 \\
\end{tabular}} & \multirow{2}{*}{$\begin{array}{l}23 \\
0 \\
\end{array}$} & \multirow{2}{*}{\begin{tabular}{|l|}
24 \\
0 \\
\end{tabular}} & \multirow{2}{*}{$\begin{array}{l}25 \\
0 \\
\end{array}$} & \multirow{2}{*}{$\begin{array}{l}26 \\
0 \\
\end{array}$} & \multirow{2}{*}{$\begin{array}{l}27 \\
0 \\
\end{array}$} \\
\hline 1 & Management & & & & & & & & & & \\
\hline 2 & $\begin{array}{l}\text { Work that requires } \\
\text { specialist knowledge }\end{array}$ & 0 & 0 & 2 & 0 & 1 & 2 & 4 & 2 & 3 & 0 \\
\hline 3 & $\begin{array}{l}\text { Work that requires higher } \\
\text { education }\end{array}$ & 0 & 2 & 0 & 0 & 2 & 1 & 1 & 6 & 7 & 9 \\
\hline 4 & $\begin{array}{l}\text { Office and customer service } \\
\text { work }\end{array}$ & 0 & 0 & 0 & 0 & 0 & 0 & 0 & 0 & 0 & 0 \\
\hline 5 & $\begin{array}{l}\text { Service, care, and sales } \\
\text { work }\end{array}$ & 22 & 40 & 70 & 71 & 70 & 68 & 73 & 74 & 70 & 82 \\
\hline 6 & $\begin{array}{l}\text { Work in farming, } \\
\text { gardening, forestry, and } \\
\text { fishing }\end{array}$ & 0 & 0 & 0 & 0 & 0 & 0 & 0 & 0 & 0 & 0 \\
\hline 7 & $\begin{array}{ll}\text { Unskilled labour } & \text { in } \\
\text { construction } & \text { or } \\
\text { manufacturing } & \\
\end{array}$ & 0 & 0 & 0 & 1 & 1 & 0 & 0 & 0 & 0 & 0 \\
\hline 8 & $\begin{array}{l}\text { Machine operator work, } \\
\text { transport work, etc. }\end{array}$ & 0 & 0 & 2 & 1 & 0 & 1 & 1 & 2 & 0 & 0 \\
\hline 9 & $\begin{array}{l}\text { Work without requirements } \\
\text { for special training }\end{array}$ & 6 & 13 & 8 & 8 & 11 & 8 & 7 & 4 & 10 & 9 \\
\hline 0 & Military work & 0 & 0 & 0 & 0 & 0 & 0 & 0 & 0 & 0 & 0 \\
\hline & Unknown & 72 & 46 & 20 & 20 & 15 & 20 & 13 & 12 & 10 & 0 \\
\hline
\end{tabular}


It is clear from the table that the occupational distribution differs greatly between men and women. A very high proportion of women have service, care, and sales jobs. More than 90 per cent of those working in this field are employed in health and social care. Many of the men have traditional blue-collar jobs, such as unskilled labour in construction, manufacturing, machine operator work, transport work, etc., as well as work that does not require special training. Few women or men have jobs that require higher education. It is particularly common in the younger age groups to work in unknown fields.

In Table 12, we will show the salary income of those who are employed. We have observations for a total of 1,634 men and 1,394 women for 2012. We have not taken into account that some people work different hours at different times of year, and a different number of hours each week. We can see that the salary income increases with age.

Table 12. The average income for those with a salary in 2012 (in SEK thousand), divided by age.

\begin{tabular}{|l|l|l|l|l|l|l|}
\hline Age & \multicolumn{5}{|l}{ Men } & \multicolumn{3}{l}{ Women } \\
\hline & All & $\begin{array}{l}\text { Those who } \\
\text { combine } \\
\text { work with } \\
\text { studies }\end{array}$ & $\begin{array}{l}\text { Those who } \\
\text { do not } \\
\text { combine } \\
\text { work with } \\
\text { studies }\end{array}$ & $\begin{array}{l}\text { Those who } \\
\text { combine } \\
\text { work with } \\
\text { studies }\end{array}$ & $\begin{array}{l}\text { Those who } \\
\text { dombine not } \\
\text { work with } \\
\text { studies }\end{array}$ \\
\hline 18 & 61.7 & 52.7 & 108.2 & 43.2 & 43.3 & 42.5 \\
\hline 19 & 81.6 & 70.3 & 112.6 & 73.2 & 70.5 & 79.7 \\
\hline 20 & 128.5 & 114.3 & 141.6 & 112.6 & 99.3 & 134.6 \\
\hline 21 & 152.6 & 129.6 & 164.6 & 125.8 & 115.2 & 139.9 \\
\hline 22 & 174.7 & 144.0 & 186.3 & 133.1 & 118.8 & 140.4 \\
\hline 23 & 181.7 & 141.7 & 194.7 & 136.5 & 127.7 & 141.5 \\
\hline 24 & 198.8 & 161.2 & 209.8 & 156.7 & 131.5 & 171.9 \\
\hline 25 & 234.0 & 221.0 & 237.3 & 172.5 & 185.3 & 166.3 \\
\hline 26 & 234.1 & 190.1 & 246.5 & 168.7 & $*$ & 166.2 \\
\hline 27 & 243.4 & $*$ & 249.3 & 206.4 & $*$ & 198.2 \\
\hline
\end{tabular}

* Too few observations 
As might be expected, the men have higher incomes than the women. This may be due to differences in hourly wages, as well as differences in the number of hours worked throughout the year. We will return to this issue in a future report. What we can see from Table 12 is that those who do not combine work with studies have higher incomes (with the exception of women aged 18 or 25). The differences in income between men and women still remain with this division. These differences are not due to a few particularly high values for some who combine work and studies - they persist if we instead compare median values (SEK 181.3 thousand compared to SEK 165.0 thousand).

\section{Neither working nor studying}

In recent years, NEET (Not in Employment, Education, or Training) has been used more frequently to study the proportion of young people having difficulties establishing themselves in adult life. Here we will present data concerning the proportion of unaccompanied minors at different ages that are not in employment or education (we have no data concerning how many are in practical training).

Table 13. Proportion (\%) of those aged 16-27 who are not in employment or education.

\begin{tabular}{|l|l|l|}
\hline Age & Women & Men \\
\hline 16 & 30 & 28 \\
\hline 17 & 25 & 16 \\
\hline 18 & 14 & 5 \\
\hline 19 & 19 & 6 \\
\hline 20 & 28 & 13 \\
\hline 21 & 29 & 18 \\
\hline 22 & 31 & 17 \\
\hline 23 & 30 & 19 \\
\hline 24 & 28 & 14 \\
\hline 25 & 22 & 16 \\
\hline 26 & 33 & 17 \\
\hline 27 & 39 & 18 \\
\hline
\end{tabular}

We know from the previous section that women are more often studying and men are more often employed. Table 13 shows that the employment gap is more prominent. Many more 
women than men are neither working nor studying. It is important to examine more closely what causes this difference. If we compare people from different countries, the proportion of those who are neither working nor studying is particularly high among women from Iraq and Somalia. Work refers to employment in November, and education refers to the autumn semester. This means that some of those who, according to the table, are neither working nor studying may have done so at other times of the year.

\section{Summary}

This report provides a general overview of the development of the number of unaccompanied minors and their situation in Sweden. Future reports will provide more detailed information about specific topics. The number of unaccompanied minors has increased over the past ten years. Sweden is the European country that receives the most children from this group. Some of them emigrate after a period of time in Sweden, but the vast majority stay.

Most of the arriving children are teenage boys who have not yet turned 18. However, the largest increase over the latest years is observed for the younger age groups. Furthermore, gender composition is also age dependent, where it is quite balanced for the younger age groups unlike the oldest age group. In the years following their arrival, most of them are enrolled in school - in relative terms, more boys than girls. When it comes to those aged 20 or over, the proportion undergoing education is higher among women. On the other hand, a higher proportion of men are employed. The group that neither works nor studies is much larger among women than among men in all age groups. We do observe a decline in educational enrolment and an increase in employment rates especially in the case of males at the age where they lose financial support from the state, which is age 21.

In future reports, we will discuss the unaccompanied minors' education and employment situation in more detail, in addition to issues concerning health and housing. ${ }^{20}$

\footnotetext{
${ }^{20}$ See Svendsen, Thorshaug, and Berg (2010) for a Norwegian study that demonstrates the importance of housing arrangements for the unaccompanied minors.
} 


\section{References}

Aalandslid, Vebjørn och Anette Walstad Enes (2012), Enslige mindreårige flyktninger i arbeid og utdanning, Statistisk sentralbyrå, Oslo, Rapport 13/2012.

Aronsson, Bernice, C Wiberg, P Sandstedt och Anders Hjern (2009), ”Asylum-seeking children with severe loss of activities of daily living: clinical signs and course during rehabilitation”, Acta Pcediatrica, Vol. 98(12), pp. 1977-1981.

Backlund, Åsa, Riitta Eriksson, Katarina von Greiff och Eva-Marie Åkerlund (2012), Ensam och flyktingbarn - barnet och socialtjänsten om den första tiden i Sverige, FOU-Södertörn, Forkningsrapport 2012:1.

Bunar, Nihad (2012) ”Utvärdering av projektet Ensamkommande barn i Stockholms län: Samordning av kommunstöd och kommunsamarbete”, KSL, kommunförbundet Stockholms Län.

Edmonds, Eric V. och Maheshwor Shrestha (2013), ”Independent child labor migrants” i Amelie F. Constant och Klaus Zimmermann (red.), International Handbook of the Economics of Migration, Cheltenham, UK: Edward Elgar.

Eide, Ketil (2000), ”Barn i bevegelse. Om oppvekst og levekår for enslige mindreårige flyktninger”, Porsgrunn: Høgskolen i Telemark, Avdeling for helse- og socialfag.

Eide, Ketil och Anders Hjern (2013), ”Unaccompanied refugee children - vulnerability and agency”, Acta Pcediatrica Vol. 102(7), pp. 666-668.

Hirvonen, Katrina (2013), “Sweden: when hate becomes the norm”, Race \& Class, Vol. 55(1), pp. 78-86.

ILO (2009), Training Manual to Fight Trafficking in Children for Labour, Sexual and Other Forms of Exploitation. Understanding Child Trafficking, Genève: ILO.

Mapsec (2013), ”Ensamkommande flyktingbarns etablering i samhällslivet - en kunskapssammanställning”, Rapport till Arbetsmarknadsdepartementet, december 2013.

Nielsen, Signe S., Marie Norredam, Karen L. Christiansen, Carsten Obel, Jørgen Hilden och Allan Krasnik (2008), ”Mental health among children seeking asylum in Denmark - the effect of length of stay and number of relocations: s cross-sectional study”, BMC Public Health, Vol. 8: 293. 
Ní Raghallaigh, Muireann (2013), “The causes of mistrust amongst asylum seekers and refugees: Insights from research with unaccompanied asylum-seeking minors living in the Republic of Ireland”, Journal of Refugee Studies, Vol. 27(1), pp. 82-100.

Olsson, Erik, Catarina Lundqvist och Alireza Behtoui (2012), “Unga migranters studiebenägenhet”, Resultatdialog, Vetenskapsrådets rapportserie, 7: 2012.

Olze, A., W. Resinger, G. Geserick och A. Schmeling (2006), “Age estimation of unaccompanied minors. Part II. Dental aspects”, Forensic Science International, 159S, S65S67.

Renwick, Danielle (2014), “The U.S. Migrant Influx”, Council on Foreign Affairs, Washington.

Schmeling, A., W. Resinger, G. Geserick och A. Olze (2006), “Age estimation of unaccompanied minors. Part I. General considerations”, Forensic Science International, 159S, S61-S64.

Stabell Wiggen, Kjersti (2014), Enslige mindreårige flyktninger, 2011. Arbeid, utdanning og inntekt, Statistisk sentralbyrå, Oslo, Rapport 2014/9.

Statistiska Centralbyrån (2013), Ensamkommande barn 2002-2012. Rapport.

Stinchcome, Dennis och Eric Hershberg (2014), “Unaccompanied Migrant Children from Central America. Context, Causes and Responses”, CLAS Working Paper Series No. 7, Washington D.C.

Stretmo, Live och Melander, Charlotte (2013), "Får jag vara med? Erfarenheter från ensamkommande barn och ungdomar i Göteborgsregionen och arbetet med denna grupp”, FoU i Väst, Rapportserie, 2:2013.

Svendsen, Stina, Kristin Thorshaug och Berit Berg (2010), Boløsninger for enslige mindreårige flyktninger. Erfaringer fra to bykommuner, Trondheim: NTNU Samfunnsforskning AS.

Tallberg Broman, Ingegerd (2014), ”Barns och ungas utbildning i ett segregerat samhälle. Mångfald och migration i valfrihetens skola”, Vetenskapsrådets rapportserie.

Thorshaug, Kristin och Stina Svendsen (2014), Helhetlig oppfølging. Nyankomne elever med lite skolebakgrunn fra opprinnelselandet og deres opplæringsituasjon, Rapport, Trondheim: NTNU. 
Vervliet, Marianne, Melinda A. Meyer Demott, Marianne Jakobsen, Eric Broekaert, Trond Heir och Ilse Derluyn (2014), ”The mental health of unaccompanied refugee minors on arrival in the host country”, Scandinavian Journal of Psychology, Vol. 55, pp. 33-37.

Wadensjö, Eskil (2013), Övertäckning och bortfall, Sulcis Rapport 2013:3. 